\title{
Pigmental Composition of Freshwater Algae at Different Levels of Nitrogen and Physico- chemical Parameters of Palhi River, Baybay, Leyte
}

\author{
Angelica Joy G. Yu and Felix M. Salas \\ Department of Pure and Applied Chemistry, Visayas State University, Baybay City, \\ Leyte 6521 - A, Philippines
}

\section{ABSTRACT}

Freshwater algae are a diverse group of organisms which impart important functions in the ecosystem pertaining to water quality. Cultured freshwater algae were used to determine the effects of nitrogen in different levels on the pigment composition, chlorophyll $a$, chlorophyll $b$ and total carotenoids. A three-month study of some physico-chemical properties of Palhi River as well as pigment content of freshwater algae was conducted to find correlations on the different parameters with that of the pigment concentration.

Results of the study showed a strong positive correlation between chlorophyll a and nitrogen level, yet a weak correlation with chlorophyll $b$ and total carotenoids on cultured freshwater algae. Both pH (6.06-6.92) and total dissolved solids (249-397 ppm) of Palhi river are within the standard limits set by DENR, WHO and USEPA. However, the average total suspended solids $(63.0 \mathrm{ppm})$ and total nitrogen $(10.3 \mathrm{ppm})$ exceeded that of the tolerable limits set by national and international standards. The pigment composition of the freshwater algae showed a strong negative correlation with the nitrogen level in Palhi River which could be attributed to the dynamics, biodiversity and complexities of the river system.

Keywords: culture, DENR, Palhi river, pigment, US EPA, water quality, WHO

\section{INTRODUCTION}

Nowadays, water quality monitoring programs have been of much value since they provide information on the assessment of water conditions in terms of natural variability, human effects and intended uses (Chapman, 1992). Specific variables, which give general indications of water health, have been of primary concern (Robertson \& Davis, 1993). The prime for evaluating the water quality is the algal growth (Bruun, 2012). Algae are very diverse group of organisms that have important functions in the ecosystem (Ramaraj et al., 2010). They are valuable in this field of study because they respond quickly to changes in the water chemistry (Bruun, 2012). They are used in the primary production quantification, nutrient status and harmful algal bloom monitoring and for drinking water managements. More importantly, they create their own chemical energy in the 
process known as photosynthesis and are commonly referred to as the primary producers within the aquatic ecosystem (Sanders, 2000). Algal growth can be measured by means of analyzing their pigment composition (Cevik et al., 2005). The photosynthetic pigments of freshwater algae are essential in the life of the said organisms because they determine algal color and help capture photosynthetic active radiation (PAR) from the sun. Specifically, the chlorophyll concentration is the key biochemical component responsible for photosynthesis (Rabinowitch \& Govindjee, 1965).

Correlations between the pigment concentrations and other water quality parameters are being studied in order to make decisions regarding water treatment (Jones \& Lee, 1982). Nutrient availability is a key factor that affects algal growth (Yonkey, 2004). Nitrogen and phosphorus are the primary limiting macronutrients in freshwater (USEPA, 2000). These nutrients are important for the growth of algae and other plants because algae in particular can grow rapidly when the nutrients $\mathrm{N}$ and $\mathrm{P}$ are abundant, often developing into single or multiple species bloom (USEPA, 2000). Yet, algal growth can be overstimulated when an excess of these nutrients are present in the water. Nutrient enrichment studies have been conducted (Biggs, 2000) since the primary production of algae can be limited by these nutrients (Dodds, 2002). According to Hassan et al. (2008), different responses were pointed out among 64 algal taxa, by means of total cell number of the differential enrichment of nutrient treatments. In fact, the availability of nitrogen mitigate the growth of Chlorella kessleri microalgae as pointed out by Horvatic et al. (2005).

.Furthermore, nutrient variability and algal pigment characteristics are used to evaluate the water quality and the degree of eutrophication in a water body. The correlation of pigment composition with nutrient levels and physico-chemical parameters could help characterize the current condition of Palhi River system. Hence, this study has been conducted to investigate the pigment composition of freshwater algae in Palhi River, assess the effects of varying levels of nitrogen on pigment concentration of algae, and evaluate the water quality of Palhi River through pigmental analysis and physico-chemical properties.

The study focused on determining chlorophyll $a$, chlorophyll $b$ and total carotenoids of freshwater algae, and physico-chemical properties such as $\mathrm{pH}$, total dissolved solids (TDS), total suspended solids (TSS), and total nitrogen of Palhi River and then correlating them for water quality evaluation. This was conducted from May to October 2014 and chemical analysis were done at the Department of Pure and Applied Chemistry and at Philrootcrops, Visayas State University, Visca, Baybay City, Leyte.

\section{MATERIALS AND METHODS}

\section{Sample Collection}

Samples of green colored freshwater algae attached on riverstones, for both the culture and physico-chemical studies were collected in the midstream of the river from the most abundantly growing area and for the entire analysis, both the water and freshwater algae samples were obtained in the same sampling point to minimize ecological variation. For the culture sampling which was made last May 
14, 2014, 50-L black buckets were used as sample containers and were brought immediately to lower campus in VSU for the culture set-up. For the physicochemical sampling one-liter acid-washed polyethylene bottles were used as sample containers for the water samples and small centrifuge tubes covered with carbon paper were used as containers for the freshwater algae samples. Samplings were done for three consecutive months, during the first week of August, September and October of 2014.

\section{Preparation and Culture of Freshwater Algae at Different Levels of Nitrogen}

The freshwater algae were cultured in the vegetable nursery area situated in the lower campus of the DOH-CAFS. The culture tanks, filled with 152 liters of water (in a ratio of 1:4 river water: tap water in VSU) with an aerator to supply enough oxygen on the tanks. The water was changed every week to ensure algal growth. A completely randomized design was followed using the following nitrogen treatments at constant total phosphorus concentrations:

Treatment 1: river water only

Treatment 2: $300 \mathrm{ppb} \mathrm{N}$

Treatment $3: 30 \mathrm{ppb} \mathrm{N}$

Treatment 4: $600 \mathrm{ppb} \mathrm{N}$

Treatment 3 served as the nutrient criteria limits recommended to prevent water quality degradation in streams and nuisance conditions (USEPA, 2000). There were 3 replicates for each treatment which were monitored for their pigment concentrations every week for three weeks.

\section{Pigmental Analysis of Freshwater Algae}

Freshwater algae were soaked in $80 \%$ of acetone for two hours to extract the pigments. Chlorophyll $a, b$ and total carotenoids were analyzed using the UV- Vis spectrophotometer set at 662, 645, and $470 \mathrm{~nm}$ wavelengths following the method of Dere et al. (1998). The analysis included the pigment composition of both the cultured algae and the fresh algae from the Palhi River collected in situ.

\section{Physico-Chemical Characterization of Palhi River}

$p H$

The $\mathrm{pH}$ of the samples was measured potentiometrically in the laboratory using an Oakton multimeter (serial \# 634212), previously calibrated with buffer solutions ( $\mathrm{pH} 4, \mathrm{pH} 7$ and $\mathrm{pH} 10)$. The electrode was rinsed with distilled water prior to each measurement.

\section{Temperature}

Water temperature was determined in situ using a thermometer directly immersed in the source of water until a constant reading was obtained. 
Temperature was expressed in degrees Celsius, ${ }^{\circ} \mathrm{C}$.

\section{TotalDissolved Solids}

One hundred (100) $\mathrm{mL}$ of each of the water sample was used in determining the total dissolved solids (in ppm) with an Oakton multimeter (serial \# 634212). The probe was rinsed with distilled water prior to each measurement. This was done in triplicate (Salas, 2012).

\section{Total Suspended Solids}

One liter of water sample was filtered in a pre-weighed filter paper (Sartorius filter paper). The filter paper and the residue were dried in an oven at $103^{\circ} \mathrm{C}$ to $105^{\circ} \mathrm{C}$ for one hour, placed in a desiccator then weighed in an analytical balance. The procedure was repeated until a constant weight was obtained. This was done in triplicate (Salas, 2012).

$$
\mathrm{TSS} \text { mg/L }=\frac{\left(\mathrm{W}_{2}-\mathrm{W}_{1}\right)}{\mathrm{V}}
$$

where: $\mathrm{W}_{1}=$ weight $(\mathrm{g})$ of the filter paper

$\mathrm{W}_{2}=$ weight $(\mathrm{g})$ of the filter paper + dried residue

$\mathrm{V}=$ volume $(\mathrm{L})$ of the sample used

Nitrogen Analysis

The Kjeldahl method was used to analyze the total nitrogen content of the water samples, in which it determined both the organic nitrogen and ammonium forms. The analysis involved a preliminary digestion to convert the organic nitrogen to ammonia, which was followed by distillation of the total ammonia into an acid absorbing solution (Black, 1965). The detailed procedure is found in Appendix II, with the formula for computation of percentage of nitrogen obtained.

\section{Statistical Analysis}

A one-way Analysis of Variance (ANOVA) and Tukey's HSD test was adopted for comparing significant differences among the pigmental composition at different nitrogen treatments and control in algal culture.

\section{WaterQuality Evaluation}

Assessment of the water quality in Palhi River was made by comparing the obtained physico-chemical parameters values and the standard limits set by DENR, WHO and USEPA. Regression analysis of nitrogen level and the pigment composition of the freshwater algae were made and compared them with that of the algal culture. 


\section{RESULTS AND DISCUSSION}

Pigmental Composition (ppm) of Cultured Freshwater Macroalgae at Varying Levels of Nitrogen Under Static Water Condition

Freshwater algae can be either the direct or indirect cause of most problems related to excessive nutrient enrichment (USEPA, 2000). Nutrient enrichment has been recorded in different earlier works (Biggs, 2000; Dodds, 2002; Horvatic et al., 2005; Hassan et al., 2008) which helped to characterize the required nutrient present in freshwater algae. In the study conducted, freshwater algae were grown in cultured tanks for five weeks with each tank applied with a different amount of nitrogen at constant phosphorus concentrations. Results of the pigment composition of cultured algae at different levels of nitrogen revealed that chlorophyll a gave the highest amount among the three pigments studied for the three-week evaluation period (Table 1). The amount of chlorophyll $a$ ranged from $2.965 \mathrm{ppm}$ on the first week to $7.740 \mathrm{ppm}$ on the third week (Results of the second and third-week analyses were not shown in this paper because they have not shown significant differences). This implied that chlorophyll $a$ was the most abundant pigment in photosynthesizing organisms and its widespread occurrence played an active role in photosynthesis (Rabinowitch \& Govindjee, 1965). It also served as the best index in many phytoplankton biomass primary productivity studies (Huot et al., 2007). Consequently, the chlorophyll $b$ content of the cultured freshwater macroalgae was much lower than chlorophyll $a$. This ranged from 0.003 ppm obtained in week 1 to $3.481 \mathrm{ppm}$ recorded in week 3 .

Though both chlorophylls had common basic stuctures and only a difference in the side chain (Rabinowitch \& Govindjee, 1965), the absorption spectra varied significantly for the two which explained the difference in the absorbance obtained for both the chlorophylls as shown in Figure 1. Chlorophyll a has two absorption bands which are located in the blue-violet $(430 \mathrm{~nm})$ and red region $(660 \mathrm{~nm})$ of the spectra while that of chlorophyll $b$ absorbed light at wavelengths or bands closer to one another, blue-violet band at $453 \mathrm{~nm}$ and the red band at $643 \mathrm{~nm}$ (Rabinowitch \& Govindjee, 1965). This only suggested that the different sidechains of the two chlorophylls influenced their absorption spectra, so that light that was not significantly absorbed by chlorophyll a, at, say, $460 \mathrm{~nm}$, was instead captured by chlorophyll $b$, which absorbed strongly at that wavelength (http://www.chm.bris.ac.uk/ motm/chlorophyll/chlorophyll_h.htm). The ratio of intensities of the two bands was shifted in chlorophyll $b$ strongly in favor of the blue-violet region band compared to chlorophyll a (Rabinowitch \& Govindjee, 1965).

Table 1. Pigmental composition (ppm) of cultured freshwater algae at varying levels of nitrogen (week 1).

\begin{tabular}{ccccc}
\hline \multirow{2}{*}{ Treatment } & \multicolumn{4}{c}{ Pigmental compositions (ppm) } \\
\cline { 2 - 5 } & Chlorophyll $a$ & Chlorophyll b & Total chlorophyll & Total carotenoids \\
\hline T1 = control & $3.555^{\mathrm{ab}}$ & 0.622 & 4.177 & $2.161^{\mathrm{b}}$ \\
$\mathrm{T} 2=30 \mathrm{ppb} \mathrm{N}$ & $2.965^{\mathrm{b}}$ & 0.046 & 3.011 & $2.110^{\mathrm{ab}}$ \\
$\mathrm{T} 3=300 \mathrm{ppb} N$ & $4.538^{\mathrm{ab}}$ & 1.616 & 6.154 & $2.218^{\mathrm{b}}$ \\
T4 $=600 \mathrm{ppb} \mathrm{N}$ & $7.200^{\mathrm{a}}$ & 0.003 & 7.203 & $4.713^{\mathrm{a}}$ \\
\hline
\end{tabular}

Values with the same letter/s assignment means they are significantly different. 


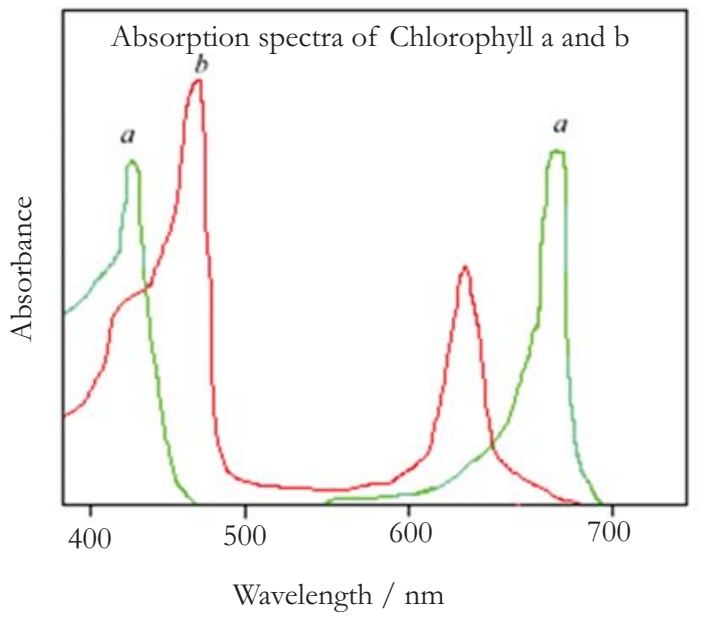

Figure 1. Absorption spectra of chlorophyll $a$ and $b$ (www.chm.bris.ac.uk)

Nutrient availability can be a key factor that can affect algal growth (Yonkey, 2004). Therefore, their pigment composition can greatly vary with the nutrient/s present. The different levels of nitrogen applied to cultured freshwater algae showed a significant effect to their pigment content. For week 1, treatment 4, with the highest amount of nitrogen applied at $600 \mathrm{ppb}$ gave the highest chlorophyll a and total carotenoids content, which were significantly different from the other treatments. However, the addition of $300 \mathrm{ppb}$ of nitrogen and the control had no significant difference on the chlorophyll $a$ and total carotenoids which showed that the $300 \mathrm{ppb}$ nitrogen level did not show any effect on the pigment content of the algal culture. This suggested that an amount of less than $600 \mathrm{ppb}$ of nitrogen can attenuate the growth of cultured freshwater algae, indicated by their pigment composition. The algae that were obtained in Palhi River were grown in an environment (static water) different from where they were actually growing (flowing river water) which has possibly affected their growth response. Rainfall data obtained in VSU PAG-ASA showed that prior to the second analysis (week 2) conducted last June 9, 2014, a heavy rain was recorded (51.4 mm of rain) the day before and four days before the third analysis conducted last June 16, 2014, still another heavy rain $(38.0 \mathrm{~mm})$ was noted. Moreover, changes in the physical appearance of the cultured freshwater algae, which at the start of the culturing process was yellow green and in the third week ended up with a slightly brownishgreen in color which illustrated they were no longer suitable for further studies on pigment composition. In addition, a small difference was observed on the pigment content of the cultured freshwater algae in the four treatments as the week of the analysis progressed which showed that nutrient availability was not anymore a factor in algal growth because of the indicated reasons above.

Furthermore, correlations of pigmental composition and nitrogen level on each treatment showed that for the three-week monitoring, chlorophyll a gave the highest correlation coefficient which supported the findings of its universal presence in all photosynthesizing organisms. But it continually decreased as the week passed by which suggested that different nitrogen levels for the proceeding weeks had no more significant effect on the pigment composition of the cultured freshwater algae. The same results were exhibited by chlorophyll $b$ and total carotenoids. 


\section{Pigmental Analysis of Freshwater Algae and Physico-ChemicalParameters of Palhi River}

The pigment content of freshwater algae of Palhi River can be influenced by the physico- chemical properties of water. Results of the pigmental analysis of freshwater algae and physico-chemical properties of Palhi River in three months' time showed that chlorophyll $a$, chlorophyll $b$ and total carotenoids content of the freshwater algae were highest in the first month of the study and lowest in the second month (Table 2). On the contrary, the nitrogen levels of the water sample were lowest in the first month which indicated that other factors could have possibly promoted the abundance in the pigment concentration. Based on the rainfall data obtained in VSU PAG-ASA, no rainfall was recorded two weeks prior to the conduct of the first analysis in Palhi River last August 7, 2014, so that the capture of light from the sun was fully optimized for algal growth. For the second month, the nitrogen level of water was at its highest yet the pigment content of freshwater algae were at their lowest, which still correlated with the rainfall data in which most of the days prior to the experimental study last September 9, 2014, heavy rains were recorded. These results contradicted to the studies made in different journals and articles (USEPA, 2000; Horvatic et al., 2005; Dodds, 2002; Deas \& Orlob, 1999). In a study conducted by Yonkey (2004), high nutrient levels resulted in lower levels of algal growth and high algal growth can be associated with lower level of nutrients.

Table 2. Pigmental analysis of freshwater algae and physico-chemical parameters in Palhi River.

\begin{tabular}{ccccccccc}
\hline Months & $\begin{array}{c}\text { Chlorophyll } \\
\mathrm{a}(\mathrm{ppm})\end{array}$ & $\begin{array}{c}\text { Chlorophyll } \\
\mathrm{b}(\mathrm{ppm})\end{array}$ & $\begin{array}{c}\text { Total } \\
\text { chlorophyll } \\
(\mathrm{ppm})\end{array}$ & $\begin{array}{c}\text { Total } \\
\text { carotenoids } \\
(\mathrm{ppm})\end{array}$ & $\mathrm{pH}$ & $\begin{array}{c}\text { TDS } \\
(\mathrm{ppm})\end{array}$ & $\begin{array}{c}\text { TSS } \\
(\mathrm{ppm})\end{array}$ & $\begin{array}{c}\mathrm{N} \\
(\mathrm{ppm})\end{array}$ \\
\hline 1 & 31.133 & 14.221 & 45.354 & 15.080 & 6.92 & 249 & 1.1 & 0.5 \\
2 & 6.733 & 0.938 & 7.671 & 3.533 & 6.05 & 333 & 71.3 & 16.8 \\
3 & 14.080 & 7.341 & 21.421 & 6.073 & 6.27 & 397 & 116.7 & 13.5 \\
\hline
\end{tabular}

Pigment composition of freshwater algae and nutrient availability in river system can be influenced by the velocity or flow of the water in the river (Berkman \& Canova, 2007; Mactal \& Carlton, 1995). The flow of a river also affects the concentration and distribution of nutrients. Nutrient concentrations are higher in running waters due to the point and non-point sources that are continually inputted whether there is a high flow (wet weather) or low flow (dry weather) stream conditions (USEPA, 2000). These were the possible reasons why pigmental composition of the freshwater algae in the three-month study were higher compared to the cultured freshwater algae.

The $\mathrm{pH}$ values and amount of total dissolved solids in Palhi River did not differ significantly for the three-month study which indicated that both parameters neither affected nor had an effect on the pigment composition. On the other hand, total suspended solids differed significantly from the first month to the third month of the study. The TSS value for the first month was $1.1 \mathrm{ppm}$ only which dramatically increased to $71.33 \mathrm{ppm}$ in the second month and continually elevated to $116.67 \mathrm{ppm}$ in the third month. Algal growth is directly affected by the light intensity reaching them. An increase in the suspended solids can limit the depth to which light can penetrate the water column thus limiting the depth of the photic 
zone and primary production (Bryan, 2006). Results of the regression analysis between TSS and pigment composition showed negative relationship; however, regression analyses of the pigment composition and nitrogen level for both the cultured freshwater algae (Fig. 2) and that for the physico-chemical properties (Fig. 3) showed that chlorophyll a and total carotenoids gave the highest degree of linearity $\left(\mathrm{r}^{2}\right)$. This suggested that both pigments were the ones greatly affected by the changes in nitrogen levels in the river or in the culture.

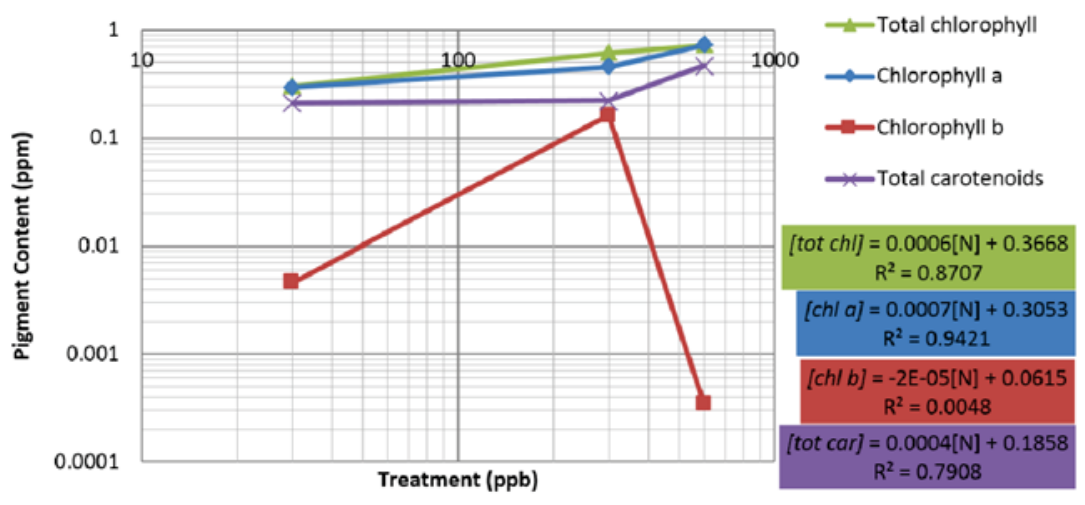

Figure 2. Correlation of pigment composition and $\mathrm{N}$ treatment level of algal culture (week 1).
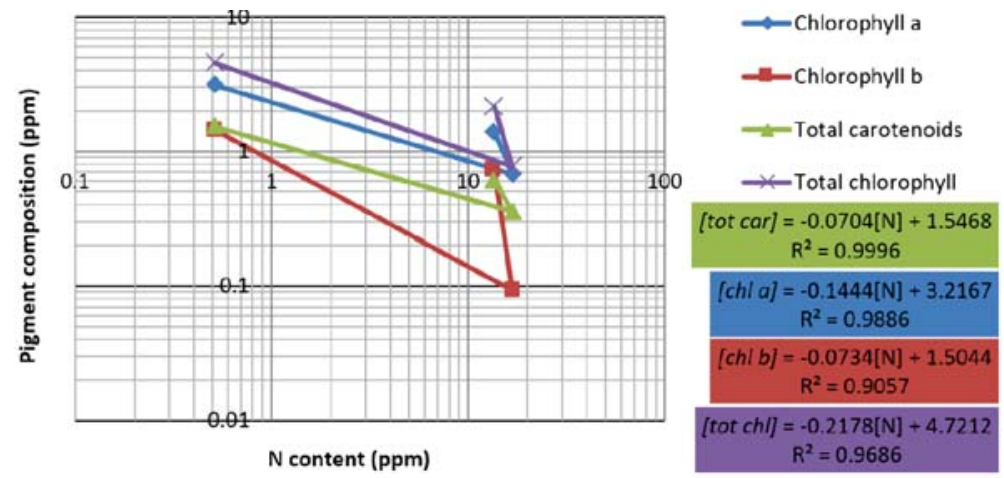

Figure 3. Correlation of pigment composition and N content in Palhi River for the three-month study of its physico-chemical properties.

\section{Assessment of WaterQuality in Palhi River Through its Physico-ChemicalProperties}

Table 3 shows the water quality assessment in Palhi River through its average physico-chemical parameters. The river had a $\mathrm{pH}$ at around 6 for the three-month study which suggested that there was a balance in the photosynthesis (during daytime) and respiration (during nighttime) of the freshwater algae as these two processes can be influential factors in $\mathrm{pH}$ fluctuations in the water system (http://www.ehow.com/info_8789087_effect-algae-pH.html).

The level of total dissolved solids for the three-month study were within the standard limits. The increase in TDS level in Palhi river which was about $84 \mathrm{ppm}$ from the first month to the second month and the third month can be attributed to 
the rainfall data obtained in VSU PAG-ASA. Days before the second and third samplings, heavy rains were recorded which caused higher inflows (NDEP, 2005) and intake of more ions due to atmospheric precipitation (Weber-Scannell \& Jacobs, 2001).

Table 3. Water quality assessment of Palhi River in terms of physico-chemical parameters.

\begin{tabular}{lcccc}
\hline $\begin{array}{c}\text { Physico-chemical } \\
\text { Parameters }\end{array}$ & Palhi River & DENR & WHO (1996) & USEPA (1986) \\
\hline pH & 6.41 & $6.0-9.0$ & $6.5-9.2$ & $6.5-9.0$ \\
TDS (ppm) & 326 & 1000 & $600-1000$ & 500 \\
Total N (ppm) & 10.3 & 10 & 10 & 10 \\
TSS (ppm) & 63 & 50 & 50 & 50 \\
\hline
\end{tabular}

Total nitrogen in the water system refers to the sum of organic nitrogencontaining compounds and the inorganic nitrogen (Bellingham, 2000). Just like phosphorus, nitrogen is transported to the water system from rain, agricultural run-off and industrial and residential waste effluents (USEPA, 2000). The significant increase in nitrogen level from first month to second month and third month can also be attributed to the heavy rains and the higher inflow during the second and third samplings. Nevertheless, the nitrogen levels during second and third month analysis exceeded the standard limits set by the environmental organizations. Possible reasons of the high nitrogen level during these sampling periods include the storm water runoff which could carry with them the mineral forms of nitrogen taken up by plants and algae, sewage and wastewater discharge brought by the flooding during rainy days in Palhi River, animal wastes specifically from the carabao bathing in the river and the piggery just directly above the midstream of Palhi River, and the presence of bacteria and blue-green algae which converts the nitrogen in the air to ammonium forms (process known as nitrogen fixation), the nitrogen form utilized by plants and animals (Bellingham, 2000; USEPA, 2000).

Total suspended solids, which typically are composed of fine and silt particles, plankton, organic and inorganic compounds and microorganisms (Bellingham, 2000) did not pass the criteria set by the environmental organizations, which stated that there must not be an increase of 30\%. Yet the increase was much more than what was required. Just like the previous results, the TSS level rise can be attributed to run-off with large loads of total suspended solids (Kemker, 2014; Susfalk et al., 2008).

\section{WaterQuality Evaluation Through Pigmental Analysis and Physico-ChemicalParameters}

Three sampling periods were set for the pigmental composition and physicochemical parameters in Palhi River. Since results of the first week analysis of the algal culture showed significant differences among the different treatments and the following two weeks' analysis already showed variation and fluctuation in the data, the former was given into focus for the water quality evaluation, together with the physico-chemical properties obtained in the three-month study of the river.

Regression analysis was used in the study to provide a means of defining a mathematical relationship between the two variables (USEPA, 2000). Figure 2 
shows that nitrogen in water and chlorophyll $a$ in cultured algae are highly correlated $\left([\right.$ Chlor $\left.\mathrm{A}]=0.0007[\mathrm{~N}]+0.3053 ; \mathrm{R}^{2}=0.9421\right)$ with each other. Chlorophyll $b$ and total carotenoids gave weak correlations with nitrogen. This implies that as nitrogen levels in water is increased, chlorophyll a pigment which is most abundant in freshwater algae also increased linearly. This was supported by the studies conducted by USEPA (2000), Horvatic et al .(2005), Dodds (2002), Deas \& Orlob (1999). The result of the regression analysis between nitrogen levels and pigment composition of Palhi River fresh algae collected in situ, however, revealed a negative correlation $\left([\right.$ Chlor $A]=-0.1444[\mathrm{~N}]+3.2167 ; \mathrm{R}^{2}=0.9886$ ) as shown in Figure 3 . This suggests that an increase in the nitrogen level in the river system can cause a decline in the pigment composition of the freshwater algae as a result of ecological imbalance.

Nevertheless, it is possible that the pigmental composition are not only affected by nitrogen and total solids but also with other factors which were not included in this research venture. Possible dependency of pigment composition on other factors is quite complex but the possibility of relating it with water quality is still possible.

\section{SUMMARY}

Pigmental composition of freshwater algae at different levels of nitrogen and physico-chemical parameters of Palhi river were studied to evaluate its water quality. Freshwater macroalgae are cultured to determine their pigment content, specifically, chlorophyll $a$, chlorophyll $b$ and total carotenoids when levels of nitrogen are varied. Results of the first week analysis showed a strong, positive correlation between the pigments chlorophyll a, total carotenoids and nitrogen level, which indicated the universal presence of the two pigments. Consequently, chlorophyll $b$ and nitrogen level showed weak correlation which was due to the difference in the absorption spectra of the two chlorophylls and its less abundance in photosynthesizing organisms.

The physico-chemical properties of Palhi River were assessed for three consecutive months. Results have shown that the $\mathrm{pH}$ and total dissolved solids are within the standard limits set by DENR, WHO and USEPA. However, nitrogen level and the total suspended solids exceeded the standard limits. The nitrogen level in the first month was $0.5 \mathrm{ppm}$ which increased significantly to $16.8 \mathrm{ppm}$ in the second month and on the third month, the change is not as great, but still higher than the standard limits. The amount of total suspended solids also increased significantly, from first month, which was $1.1 \mathrm{ppm}$ to second month, which was 16. $8 \mathrm{ppm}$ to the third month which already reached $116.7 \mathrm{ppm}$. Rapid increase in the nitrogen level is directly influenced by the changing weather conditions from one sampling period to another. Days prior to the second and third sampling, heavy rains were recorded and storm water run-off can bring with them different forms of nitrogen. The tremendous increase of the amount of total suspended solids from first to the last sampling can be highly caused by the heavy rainfall, flooding and flow water velocity.

Results of the pigmental composition of cultured freshwater algae at different levels of nitrogen and physico-chemical properties of Palhi River showed that the amount of chorophyll a gave the best fit among the pigments in terms of nitrogen 
concentration. On the other hand, results of the regression analysis of the pigmental composition of the freshwater algae for the physico-chemical characteristics of Palhi River have showed a strong, negative correlation particularly on nitrogen level which implied that another parameter might have caused this decrease in pigment composition though the amount of nitrogen increased significantly. Pigment composition decreased as total suspended solids level increased. This might have caused some effects on light penetration into the water column thereby affecting light absorption for photosynthetic activity necessary for the pigment development of algae.

\section{CONCLUSION}

Based on the results, the following conclusions are made:

1. The freshwater algae in Palhi river have chlorophyll a of $6.733-31.133 \mathrm{ppm}$, chlorophyll b of 0.938 - 14.221 ppm and total carotenoids of $3.533-15.080$ ppm;

2. Chlorophyll $a$ in fresh algae has a strong correlation with the nitrogen level in water;

3. The $\mathrm{pH}$ and the level of total dissolved solids in Palhi River are within the water quality standard limits set by DENR, USEPA and WHO; however, the amount of nitrogen and total suspended solids are beyond the prescribed limits.

\section{RECOMMENDATIONS}

For the improvement of the study, the following recommendations are suggested:

1. Determine the specific algal species that will be used in further studies;

2. Evaluate algal culture under flowing system;

3. Study on other pigments for algal studies;

4. Culture freshwater algae in a more appropriate simulated environment;

5. Specify more sampling sites, sampling periods and water quality parameters to support a better water quality assessment;

6. Identify a water quality index as a unitless quantity that is used for water quality evaluation;

7. Establish the order of correlation between pigment composition and physico-chemical parameters;

8. Monitor the physico-chemical properties of the water used in algal culture; and

9. Conduct algal studies for disaster prediction and climate change adaptation.

\section{ACKNOWLEDGMENT}

The authors would like to acknowledge the funding support given by the Visayas State University (VSU) for this research project. 


\section{REFERENCES}

BELLINGHAM, K. 2000. Physicochemical Parameters of Natural Waters. Available online. http:/ /www.stevenswater.com.

BERKMAN, J.H. and M. G. CANOVA. 2007. Algal biomass indicators. U.S. Geological Survey National Field Manual for the Collection of Water-Quality Data, book 9, chap. A7, 86 pp.

BIGGS, B.J. F. 2000. Eutrophication of streams and rivers: dissolved nutrient chlorophyll relationship for benthic algae. The North American Benthological Society 19(1): 17-31.

BLACK, C.A. 1965. Methods of soil analysis. Part 2. Chemical and Microbial properties. American Society of Agronomy Monograph No. 9. Madison, Winconsin. $1572 \mathrm{pp}$.

BRUUN, K. 2012. Algae can function as indicators of water pollution. Nostoca Algae Laboratory, Washington State Lake Protection Association. Available online:

www.nostoca.com.

BRYAN, R. 2006. Suspended solids and turbidity requirements of freshwater aquatic life and example relationship between TSS $(\mathrm{mg} / \mathrm{L})$ and turbidity (NTUs) for a treated municipal effluent. A technical memorandum prepared by Robertson-Bryan Inc. 23 pp.

CEVIK, F., B. DERICI, N. KOYUNKU and C. TUGYAN. 2005. The Influence of Some Physico-Chemical Criteria on Chlorophyll-a In Summer Season, in Seyhan Dam, Adana-Turkiye. In Proceedings.The $7^{\text {th }}$ Balkan Conference on Operational Research "Bacor 05"

CHAPMAN, D. 1992. Water Quality Assessments. Chapman and Hall, London, UK.

DEAS, M.L. and G.T. ORLOB. 1999. Water Quality: Nutrients and Algae. Available online:http://www.krisweb.com/krissheepscot/ $\mathrm{krisdb} / \mathrm{html} / \mathrm{krisweb} / \mathrm{stream} /$ nutrients.htm

DERE, S., T. GUNES and R. SIVACI. 1998. Spectrophotometric determination of chlorophyll a, b and total carotenoid contents of some algal species using different solvents. Tr. J. of Botany, 22:13-17

DODDS, W.K. 2002. Freshwater Ecology-Concepts and Environmental Applications. New York: Academic Press.

HASSAN, F.M., H. AL-SAADI and F. ALKAM. 2008. Laboratory study on the effects of nutrient enrichment on a phytoplankton population in sawa lake, iraq. Um-Salama Science Journal. 5(2):230-236.

HORVATIC, J., V. PERSIC and Z. POPOVIC. 2005. The assessment of nutrient availability for the growth of freshwater green algae Chlorella kessleri by bioassay. In Proceedings. The $36^{\text {th }}$ International Conference International Association for Danube Research.

http://www.chm.bris.ac.uk/motm/chlorophyll/chlorophyll-h.htm

http://www.ehow.com/info-8789087_effect-algae-pH.html

HUOT,Y., M. BABIN, F. BRUYANT, C. GROB, M.S. TWARDOWSKI and H. CLAUSTRE. 2007. Does chlorophyll a provide the best index of phytoplankton biomass for primary productivity studies. Biogeosciences Discussion. 4:707-745. 
JONES, R.A. and G.F. LEE. 1982. Chlorophyll- a raw water quality parameter. AWWA Quality Control in Reservoirs Committee Report. Available online: http://www.gfredlee.com/WSWQ/ChlorophyllRawWater.pdf

KEMKER, C. 2014. Turbidity, Total Suspended Solids and Water Clarity. Fundamentals of Environmental Measurements. Fondriest Environmental, Inc.. Web. < http://www.fondriest.com/environmentalmeasurements/parameters/water-quality/turbidity-total-suspended-solidswater-clarity/ $>$.

MACTAL, R. and R. CARLTON.1995. Relative importance of flowing water on biomass and algal taxonomy of periphyton assemblages. University of Notre Dame Environmental Research Center-East. pp. 1-30.

NEVADA DIVISION OF ENVIRONMENTAL PROTECTION (NDEP). 2005. Summary of lahontan reservoir water quality, 2003-2005. Available online: https:// ndep.nv.gov/bwqp/Lahontan / FocusGroupMtg3_12_11_13.pdf

RAMARAJ, R., D. TSAI and P.H. CHEN. 2010. Algae growth in natural water sources. Journal of Soil and Water Conservation, 42 (4) : 439-450.

RABINOWITCH, E.I and GOVINDJEE . 1965. The Photosynthetic Pigments. Chapter 9: 102-123.Available online: http://www.life.illinois.edu/ govindjee/photosynBook/Chapter9.pdf.

ROBERTSON, A. and W. DAVIS.1993. The selection and use of water quality indicators. p. 119-128. In: Water Environment Foundation (ed.). Challenges facing environmental laboratories: methods, quality, media, and liability. Specialty Conference Series, Santa Clara, CA. Water Environment Foundation, Alexandria, VA.

SALAS, F. M. 2012. Laboratory Manual in Environmental Chemistry. First Edition, Department of Pure and Applied Chemistry. Visayas State University, Visca, Baybay City, Leyte. 84 p

SANDERS, P. 2000. An Introduction to Algae Measurements Using In Vivo Fluoresecence. Available online. Hach Hydromet Website: www.hachhydromet.com

SUSFALK,R.B., B. FITZGERALD and A.M. KNUST. 2008. Characterization of turbidity and total suspended solids in the upper Carson river, Nevada. Nevada Division of Environmental Protection, Nevada System of Higher Education.61 pp.

USA ENVIRONMENTAL PROTECTION AGENCY, 2000. Nutrient Criteria Technical Guidance Manual. Office of Water. Office of Science and Technology Washington, DC 20460. Available online. www.epa.gov.

WEBER-SCANNELL,P. and L.L. JACOBS. 2001. Effects of total dissolved solids on aquatic organisms. A literature review: Technical report no. 01-06 of the Alaska department of fish and game division of habitat and restoration, $68 \mathrm{pp}$.

UNITED STATES ENVIRONMENTAL PROTECTION AGENCY (USEPA). 1986. Quality criteria for water 1986. Office of Water Regulations and Standards Washington DC. 477 pp. Available online: http://water.epa.gov/scitech/swguidance/standards/criteria/aqlife/upload /2009_01_13_criteria_goldbook.pdf

WORLD HEALTH ORGANIZATION, 1996. Total Dissolved Solids in Drinking Water. guidelines for drinking-water quality, 2nd ed. Vol. 2. 
YONKEY, S.J. 2004. Aquatic Nutrient Impact on Algae Production within Three Central Ohio Watersheds. Available online. http:/ /www.capital.edu/68/Artsand-Sciences/23608/

YSI ENVIRONMENTAL 2000. The Basics of Chlorophyll Measurement. Available online: http://www.ysi.com/media/pdfs/T606-The-Basics-ofChlorophyll-Measurement.pdf 